УДК 355.40:004.82(477)(043)

Віталій Володимирович Зуйко (кандидат військових наук, доцент)

Сергій Анатолійович Мельник

Іван Миколайович Лук'янчіков

Олексій Васильович Повещенко

Національний університет оборони Украӥни імені Івана Черняховського, Київ, Україна

\title{
МЕТОДИКА ОЦІНЮВАННЯ ІНФОРМАЦІЙНИХ ДОКУМЕНТІВ В IНТЕРЕСАХ ЗАБЕЗПЕЧЕННЯ ІНФОРМАЦІЙНОЇ ДІЯЛЬНОСТІ
}

В статті пропонується вирішення актуального наукового завдання удосконалення науковометодичного апарату оцінювання інформаційних документів при проведенні розвідувальноінформаційної діяльності в системі воєнної розвідки. Розвідувально-інформаційна діяльність - иче безперервний процес, який включає комплекс заходів з організації і ведення в загальній системі воєнної розвідки розвідувально-інформачійної, інформачійної та інформачійно-аналітичної роботи для надання розвідувальної інформачї ї̈ споживачам. Зібрати у визначені терміни, оперативно обробити, проаналізувати та вчасно доповісти це $\epsilon$ головним $i$ вирішальним завданням розвідувальноінформаційної діяльності в інтересах забезпечення прийняття рішення. Особливістю сучасної розвідувально-інформаційної діяльності є вирімення широкого кола інтелектуальних за змістом завдань, результатами яких є розробка інформаційних документів. Оичінка якості їхнього виконання є складовою частиною оцінювання інформаційно-аналітичної діяльності в изілому.

Для вирішення завдання ефективної інформаційно-аналітичної діяльності запропоновано методику оцінювання інформаційно-звітних документів. Методика основана на методі аналізу ієрархій, якій дозволяє прийняти рішення на основі неформалізованих показників, які неможливо описати аналітичними залежностями. Запропонована методика дозволить підвищити якість оцінювання інформаційних документів.

Ключові слова: розвідувально-інформачійна діяльність; воєнна розвідка; інформачійні документи; розвідувальна інформація.

\section{Вступ}

Постановка проблеми. Останнім часом розвідка стає дедалі важливішою складовою функціонування Збройних Сил України та держави в цілому. Значення i сила розвідки полягає в інформації, що добувається, в іiї своєчасній і якісній обробці та в оперативному доведенні іï до органів управління, що визначені законодавством України [1]. Тому організація та ведення ефективної інформаційно-аналітичної діяльності (ІАД) воєнною розвідкою, що передбачає етапи збору, обліку та систематизації, аналізу, оцінки, узагальнення та синтезу даних на основі інформаційних технологій у всіх сферах розвідувальної діяльності, займає провідне місце у процесі забезпечення функціонування усіх органів державної влади. Результатом ІАД $є$ розробка інформаційних та інформаційно-аналітичних документів, а оцінювання якості їхнього виконання $є$ складовою частиною заключного етапу процесу організації інформаційноаналітичної діяльності.

Аналіз останніх досліджень і публікацій. Аналіз існуючих методик i підходів оцінки показує, що вони в цілому дозволяють проводити комплексне оцінювання якості виконання документів. Однак їм притаманні суттєві недоліки, a came:

не враховані вимоги [2], що стосується визначення самого поняття "розвідувальна інформація"; не визначена загальна послідовність (алгоритм) проведення оцінювання якості виконання документів; потребують уточнення показники та критерії, за якими здійснюється оцінювання інформаційних документів (ІД); не використовуються кількісно-якісні підходи до визначення якості виконання документів.

Мета статті. Виходячи 3 цього метою статті є удосконалення методики оцінювання якості виконання інформаційних документів, в інтересах розвідувально-інформаційної діяльності (РІД) в системі воєнної розвідки.

\section{Виклад основного матеріалу дослідження}

Оцінка якості виконання ІД являє собою визначення ступеню виконання вимог, які до них висуваються керівними документами. Під ступенем виконання цих вимог будемо розуміти відповідність значень показників поточного документу значенням показників “ідеального документу".

Проведення такого порівняння передбачає прийняття рішення на основі неформалізованих показників, які неможливо описати аналітичними 
залежностями. Одним із найбільш ефективних методів вирішення завдань наведеного класу $\epsilon$ метод аналізу ієрархій (MAI) [3-6]. При цьому, використання MAI для таких цілей обумовлює наступні припущення та обмеження:

обрані показники якості виконання ІД $€$ незалежними один від одного та в повній мірі відображають вимоги, які висуваються до документів;

ступінь впливу того чи іншого показника на якість виконання документу в цілому визначається шляхом проведення парних порівнянь відносно головної мети проведення такого оцінювання;

парні порівняння показників здійснюються за допомогою шкали порівнянь, яка має 9 градацій; отримані під час парних порівнянь числові переваги є детермінованими, а не ймовірнісними величинами;

пріоритети показників якості виконання документів встановлюються шляхом проведення експертного опитування;

перевірка узгодженості думок експертів здійснюється за процедурою, яку передбачає MAI;

одночасно може проводитись оцінювання якості виконання тільки одного ІД.

Оцінювання якості виконання ІД пропонується здійснювати в кілька етапів (рисунок 1).

На першому етапі здійснюється вивчення документу та проводиться перевірка відповідності інформації, яка в ньому міститься, вимогам [2].

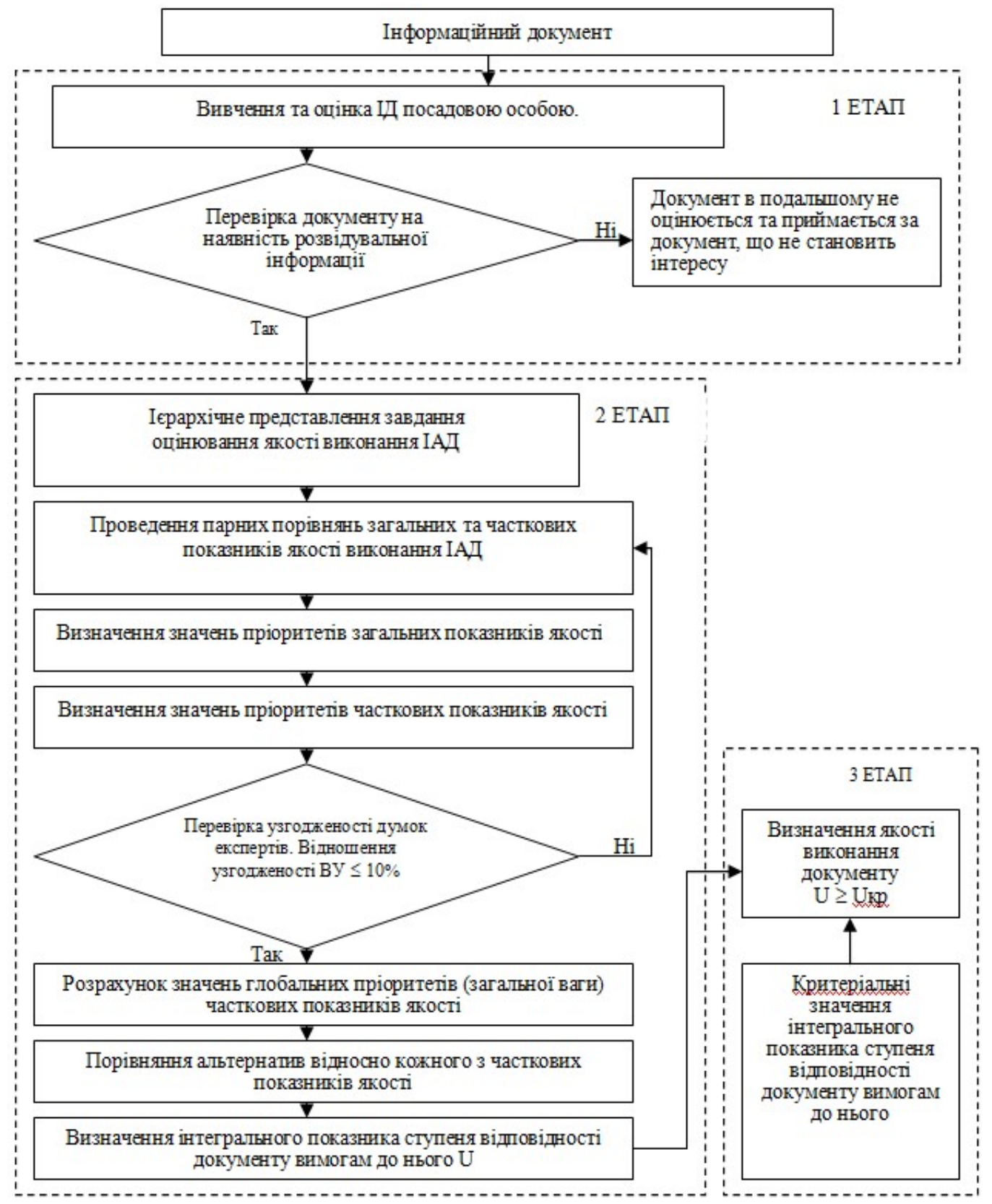

Рис. 1. Алгоритм оцінювання якості виконання інформаційних документів

Другий етап. За умов наявності в документі розвідувальну, здійснюється визначення інформації, яку можна класифікувати як інтегрального показника ступеня відповідності 86 ISSN2311-7249(Print)/ISSN2410-7336(Onfine) Сучасні інббормахійні технологї̈ ссбері безпеки та оборони № 1(37)/2020 
документу $U$ вимогам до нього за допомогою виразів:

$$
\begin{gathered}
\mathrm{U}=\frac{\mathrm{P}_{\Pi}}{\mathrm{P}_{\mathrm{I}}} 100 \%, \\
\mathrm{P}_{\Pi(\mathrm{I})}=\sum_{\mathrm{i}=1}^{\mathrm{n}} \alpha_{\mathrm{i}} \mathrm{B}_{\Pi(\mathrm{I}) \mathrm{i}},
\end{gathered}
$$

де $\mathrm{P}_{\Pi}, \mathrm{P}_{\mathrm{I}}-$ коефіцієнти відносної ваги поточного та “ідеального” документів відповідно, які отримані шляхом порівняння альтернатив відносно кожного 3 часткових показників якості виконання документів; $\alpha_{i}$ - глобальний пріоритет $i$-го показника якості виконання документу; $\mathrm{B}_{\Pi(\mathrm{I}) \mathrm{i}}$ в відносні пріоритети поточного (“ідеального”) документу, які отримані шляхом їхнього парного порівняння відносно ступеня відповідності критеріальним значенням $i$-го часткового показника якості виконання документів.
Використання MAI для визначення показника $U$ передбачає необхідність ієрархічного зображення завдання 3 оцінювання якості виконання документів. Таке ієрархічне зображення наведено на рисунку 2 [5].

Виходячи з рисунку 2 та визначених в $[5,7,8]$ загальних та часткових показників, відповідно до MAI проводяться їх парні порівняння i визначаються значення пріоритетів (вага) цих показників. Здійснюється перевірка думок експертів та розраховуються значення глобальних пріоритетів часткових показників якості виконання документів.

Глобальний пріоритет $i$-го показника якості виконання документу визначається за формулою

$$
\alpha_{\mathrm{i}}=\beta_{\mathrm{j}} \gamma_{\mathrm{i}}
$$

де $\beta_{\mathrm{j}}-$ пріоритет $j$-го загального показника відносно його впливу на загальну мету;

$\gamma_{\mathrm{i}}$ - пріоритет $i$-го часткового показника відносно свого загального показника.

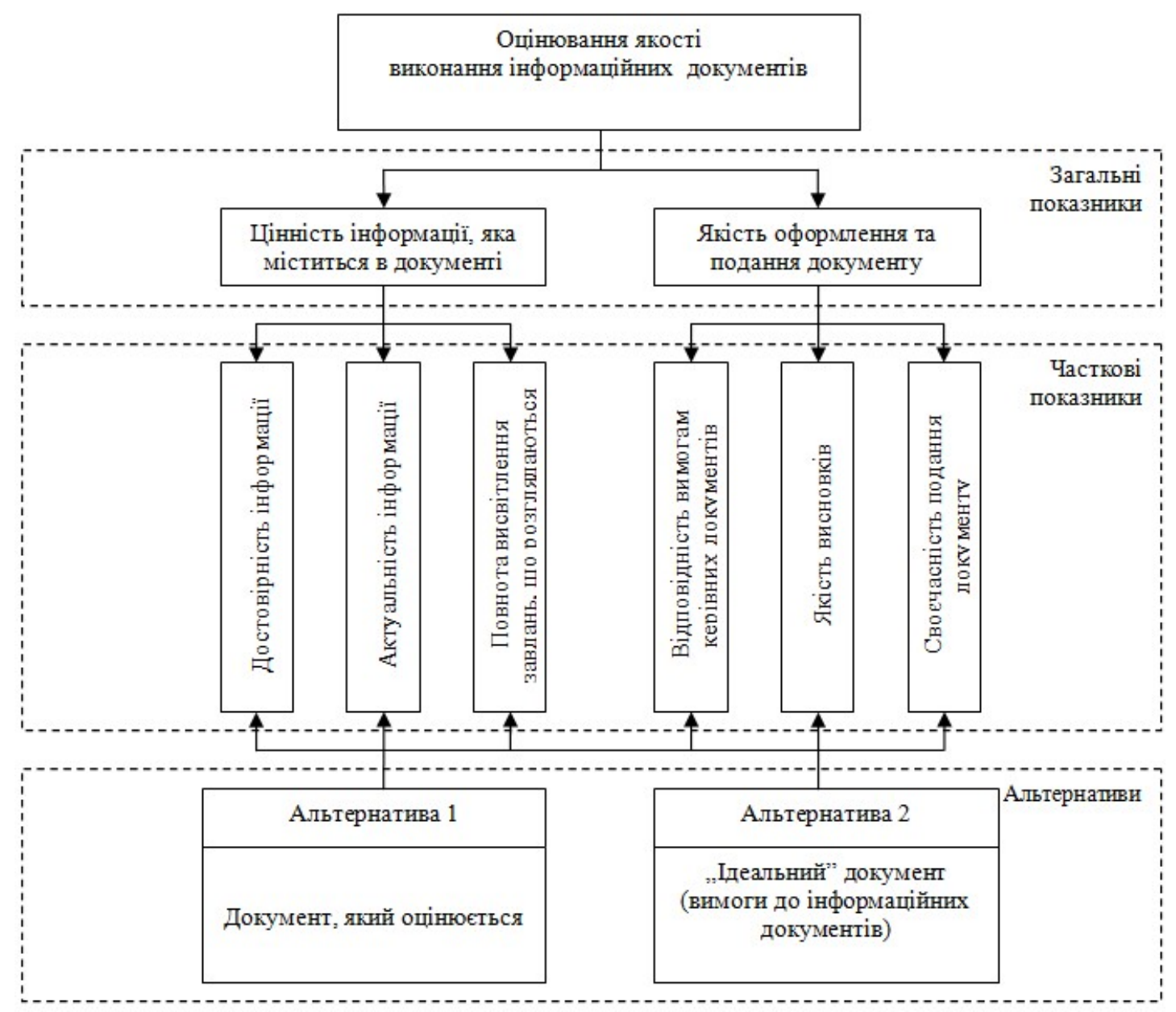

Рис. 2. Ієрархічне зображення завдання з оцінювання якості виконання інформаційних документів

Визначення значень $\beta_{j}$ і $\gamma_{i}$ здійснюється шляхом складання відповідних матриць парних порівнянь за допомогою шкали парних порівнянь.

Клітини матриці заповнюються експертами виходячи 3 таких міркувань (таблиця 1). Якщо показник $A_{1}$ домінує над показником $A_{2}$, то клітка, яка відноситься до рядка $A_{1}$ і стовпця $A_{2}$, заповнюється числом $a_{12 l}$, а клітка, яка відповідає рядку $A_{2}$ і стовпцю $A_{1}$, заповнюється оберненим числом, тобто $a_{21 l}=1 / a_{12 l}$. Якщо елементи, що 
порівнюються однакові, то у клітці на перетину одиниця [6-9]: відповідних строки та стовпця ставиться

Таблиця 1

Матриця оцінок експертів якості виконання документу

\begin{tabular}{|l|c|c|c|c|}
\hline $\begin{array}{l}\text { Загальні (часткові) } \\
\text { показники якості } \\
\text { виконання документу }\end{array}$ & $\begin{array}{c}\text { Загальний } \\
\text { (частковий) } \\
\text { показник } A_{1}\end{array}$ & $\begin{array}{c}\text { Загальний } \\
\text { (частковий) } \\
\text { показник } A_{2}\end{array}$ & $\ldots$ & $\begin{array}{c}\text { Загальний } \\
\text { (частковий) } \\
\text { показник } A_{j}\end{array}$ \\
\hline $\begin{array}{l}\text { Загальний (частковий) } \\
\text { показник } A_{1}\end{array}$ & $a_{11 l}$ & $a_{12 l}$ & $\ldots$ & $a_{1 j l}$ \\
\hline $\begin{array}{l}\text { Загальний (частковий) } \\
\text { показник } A_{2}\end{array}$ & $a_{21 l}$ & $a_{22 l}$ & $\ldots$ & $a_{2 j l}$ \\
\hline \multicolumn{1}{c}{$\cdot$} & $\cdot$ & $\cdot$ & $\ldots$ &. \\
\hline $\begin{array}{l}\text { Загальний (частковий) } \\
\text { показник } A_{i}\end{array}$ & $\cdot$ & $\cdot$ & &. \\
\hline
\end{tabular}

3 групи одержаних матриць парних порівнянь формується набір локальних пріоритетів, які виражають відносний вплив множини елементів на елемент рівня, що примикає зверху. Для цього обчислюються власні вектори для кожної матриці парних порівнянь i результат нормується. Визначення локальних пріоритетів здійснюється у такій послідовності: для кожного рядка $l$-ї матриці визначається геометричне середнє:

$$
b_{i l}=\sqrt[n]{\prod_{j} a_{i j l}}, j=\overline{1, n}, i=\overline{1, n},
$$

Потім здійснюється нормування геометричних середніх, тобто розраховуються значення пріоритетів (ваги) показників якості (загальних, часткових):

$$
\beta(\gamma)=\frac{\mathrm{b}_{\mathrm{ij}}}{\sum_{\mathrm{i}} \mathrm{b}_{\mathrm{ij}}}, \mathrm{i}=\overline{1, \mathrm{n}},
$$

Авторами були проведені дослідження, які дозволили шляхом проведення експертного опитування та застосуванні процедури MAI для обробки суджень експертів, визначити значення пріоритетів (ваги) загальних та часткових показників оцінки якості виконання документів. Відношення узгодженості думок експертів під час опитування склало менше $10 \%$, що відповідає вимогам [5, 9-11]. Значення пріоритетів (ваги) загальних та часткових показників (рисунок 2) складають відповідно:

для загального показника цінності інформації, яку містить документ, $\beta_{\mathrm{I}}=0,75$;

для загального показника якості оформлення та подання документу $\beta_{\Pi}=0,25$;

для часткового показника достовірності інформації $\gamma_{\text {д }}=0,54$;

для часткового показника актуальності інформації $\gamma_{\mathrm{A}}=0,3$;

для часткового показника повноти інформації $\gamma_{\Pi}=0,16$

для часткового показника відповідності вимогам керівним документам $\gamma_{\mathrm{K}}=0,12$; для часткового показника якості висновків $\gamma_{\mathrm{B}}=0,44$;

для часткового своєчасності подання документу $\gamma_{\mathrm{C}}=0,44$.

3 врахуванням отриманих показників глобальні пріоритети кожного часткового показника якості виконання документів будуть дорівнювати:

для часткового показника достовірності інформації $\alpha_{\text {д }}=\beta_{\text {I }} \times \gamma_{\text {д }}=0,405$;

для часткового показника актуальності інформації $\alpha_{\mathrm{A}}=\beta_{\mathrm{I}} \times \gamma_{\mathrm{A}}=0,225$;

для часткового показника повноти інформації $\alpha_{\Pi}=\beta_{\mathrm{I}} \times \gamma_{\Pi}=0,12$;

для часткового показника відповідності вимогам керівним документам $\alpha_{K}=\beta_{\Pi} \times \gamma_{K}=0,027$;

для часткового показника якості висновків $\alpha_{\mathrm{B}}=\beta_{\Pi} \times \gamma_{\mathrm{B}}=0,11$;

для часткового показника своєчасності подання документу $\alpha_{\mathrm{C}}=\beta_{\Pi} \times \gamma_{\mathrm{C}}=0,11$.

В подальшому значення розрахованих глобальних пріоритетів $\alpha_{i}$ часткових показників в методиці використовуються як константи.

Після визначення глобальних пріоритетів $\alpha_{i}$ здійснюється порівняння альтернатив (поточного та

“ідеального” документів) відносно кожного 3 часткових показників якості та визначаються їхні відносні пріритети $B_{\Pi(\mathrm{I}) i}$ :

$$
\begin{gathered}
\mathrm{B}_{\Pi}=\frac{\sqrt{1 / \mathrm{b}_{\mathrm{i}}}}{\sqrt{\mathrm{b}_{\mathrm{i}}}+\sqrt{1 / \mathrm{b}_{\mathrm{i}}}}, \\
\mathrm{B}_{\mathrm{I}}=\frac{\sqrt{\mathrm{b}_{\mathrm{i}}}}{\sqrt{\mathrm{b}_{\mathrm{i}}}+\sqrt{1 / \mathrm{b}_{\mathrm{i}}}},
\end{gathered}
$$

де $b_{i}$ - ступінь важливості при порівнянні за шкалою парних порівнянь [6].

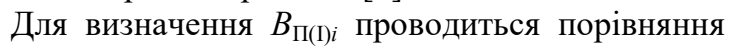
за шкалою [5] альтернатив 3 метою встановлення 
ступеню відповідності поточного документу вимогам, які висуваються до документів за $i$-м показником якості. Для цього формуються матриці парних порівнянь за кожним частковим показником (таблиця 2):

Матриця парних порівнянь за кожним частковим показником

\begin{tabular}{|l|c|c|}
\hline \multicolumn{1}{|c|}{ Альтернативи } & Поточний документ & „Ідеальний” документ \\
\hline Поточний документ & 1 & $1 / b_{i}$ \\
\hline “Ідеальний” документ & $b_{i}$ & 1 \\
\hline
\end{tabular}

Далі за формулами (1), (2) здійснюється розрахунок інтегрального показника ступеня відповідності документу вимогам до нього.

третій етап методики. Проводиться порівняння отриманого значення інтегрального показника $U 3$ його критеріальними значеннями (таблиця 3) та визначається якість виконання документу, що розглядається.

Таблиця 3

Критеріальні значення інтегрального показника ступеня відповідності документу вимогам до нього

\begin{tabular}{|c|c|c|c|}
\hline \multirow{2}{*}{$\begin{array}{l}\text { Ступінь } \\
\text { якості } \\
\text { виконання } \\
\text { документу }\end{array}$} & \multirow[b]{2}{*}{ Значення $U$} & \multicolumn{2}{|c|}{ Зміст критерію } \\
\hline & & $\begin{array}{l}\text { щодо цінності інформації, яка } \\
\text { міститься в документі }\end{array}$ & $\begin{array}{l}\text { щодо якості оформлення та } \\
\text { подання документу }\end{array}$ \\
\hline $\begin{array}{l}\text { Документ } \\
\text { особливої } \\
\text { важливості }\end{array}$ & $U \geq 86,5 \%$ & $\begin{array}{l}\text { PI, яка міститься в документі, } \\
\text { достовірна, упереджувальна та } \\
\text { повна. }\end{array}$ & $\begin{array}{lrr}\text { Документ } & \text { поданий } & \text { вчасно, } \\
\text { повністю } & \text { відповідає } & \text { вимогам } \\
\text { керівних } & \text { документів, } \\
\text { повні. } & & \\
\end{array}$ \\
\hline $\begin{array}{l}\text { Документ } \\
\text { оцінюється } \\
\text { як цінний }\end{array}$ & $86,5 \%>U \geq 65,5 \%$ & $\begin{array}{l}\text { РІ, яка міститься в документі, } \\
\text { достовірна, повна, a іï } \\
\text { актуальність висока. }\end{array}$ & $\begin{array}{lrr}\text { Документ } & \text { поданий } & \text { вчасно, } \\
\text { повністю } & \text { відповідає } & \text { вимогам } \\
\text { керівних } & \text { документів } & \text { якість } \\
\text { висновків достатня. } & \\
\end{array}$ \\
\hline $\begin{array}{l}\text { Документ } \\
\text { середньої } \\
\text { цінності }\end{array}$ & $65,5 \%>U \geq 39,7 \%$ & $\begin{array}{l}\text { PI, яка міститься в документі за } \\
\text { своєю достовірністю не нижче } \\
\text { за вірогідну, достатньо повна, її } \\
\text { актуальність достатня. }\end{array}$ & $\begin{array}{l}\text { Документ поданий } \\
\text { відповідність вимогам } \\
\text { докерівних } \\
\text { сокунтів достатня, висновки } \\
\text { середньої якості. }\end{array}$ \\
\hline $\begin{array}{l}\text { Документ } \\
\text { становить } \\
\text { iнтерес }\end{array}$ & $39,7 \%>U \geq 29,6 \%$ & $\begin{array}{l}\text { РІ, яка міститься в документі, за } \\
\text { достовірністю не нижче за } \\
\text { можливо правдиву, частково } \\
\text { повна, їі актуальність достатня. }\end{array}$ & $\begin{array}{l}\text { Документ поданий } \\
\text { відповідність вимогам кері, } \\
\text { документів посередня, висновки } \\
\text { низької якості. } \\
\end{array}$ \\
\hline $\begin{array}{l}\text { Документ } \\
\text { малої } \\
\text { цінності }\end{array}$ & $29,6 \%>U \geq 19,5 \%$ & $\begin{array}{l}\text { PI, яка міститься в документі, за } \\
\text { достовірністю } \quad \text { сумнівна, } \\
\text { низької актуальності } \\
\text { повноти. }\end{array}$ & $\begin{array}{llr}\text { Документ } & \text { поданий } & \text { вчасно, } \\
\text { відповідність вимогам } & \text { керівних } \\
\text { документів низька, } & \text { висновки } \\
\text { незадовільної якості. } & \\
\end{array}$ \\
\hline $\begin{array}{l}\text { Документ не } \\
\text { становить } \\
\text { інтересу }\end{array}$ & $\mathrm{U}<19,5 \%$ & $\begin{array}{l}\text { PI, яка міститься в документі, } \\
\text { не } \text { несе } \\
\text { навантаження, неактуальна, а їі } \\
\text { достовірність } \\
\text { визначити. Або документ не } \\
\text { містить в собі РІ. }\end{array}$ & $\begin{array}{lcr}\text { Документ } & \text { поданий } & \text { невчасно, } \\
\text { відповідність } & \text { вимогам } & \text { керівних } \\
\text { документів } & \text { та } & \text { висновки } \\
\text { незадовільні. } & & \end{array}$ \\
\hline
\end{tabular}

Розглянемо практичний приклад оцінювання якості виконання інформаційних документів за допомогою вище запропонованої методики.

Відповідно до ієрархії оцінювання якості виконання ІД (рисунок 2) здійснюємо порівняння поданого документу 3 документом, який повністю відповідає вимогам, тобто 3 “ідеальним документом”. Порівняння здійснюються окремо по відношенню до критеріальних значень кожного часткового показника якості за допомогою шкали порівнянь [5]. При цьому відповідно до [5] найвищому критеріальному значенню виставляється 1, а найнижчому - 1/9.

Припустимо, що поточний документ оцінений:

за достовірністю поданої інформації - середнє між “достовірна” та “вірогідна" (1/2);

за актуальністю поданої інформації - “висока актуальність" (1/3);

за повнотою інформації - середнє між “достатньо повна” та “часткова” (1/4);

за відповідністю вимогам керівних документів - “висока” (1);

за якістю висновків - середнє між “середньої 
якості” та “низької якості” (1/6);

за своєчасністю подання документу “вчасно" (1).

Тому, згідно 3 розробленою методикою результати порівняння поточного та “ідеального" документів за частковими показниками можна представити у вигляді таблиці 4.

Таблиця 4

Результати порівняння поточного та „ідеального” документів за кожним з часткових показників якості

\begin{tabular}{|c|c|c|}
\hline $\begin{array}{c}\text { Альтернативи } \\
\text { (документи, що порівнюються) }\end{array}$ & “Ідеальний” документ & Поточний документ \\
\hline \multicolumn{3}{|c|}{ За ступенем достовірності поданої інформації } \\
\hline “ІІдеальний” документ & 1 & 2 \\
\hline Поточний документ & $1 / 2$ & 1 \\
\hline \multicolumn{3}{|c|}{ За ступенем актуальності поданої інформації } \\
\hline “Ідеальний” документ & 1 & 3 \\
\hline Поточний документ & $1 / 3$ & 1 \\
\hline \multicolumn{3}{|c|}{ За ступенем повноти поданої інформації } \\
\hline “Ідеальний” документ & 1 & 4 \\
\hline Поточний документ & $1 / 4$ & 1 \\
\hline \multicolumn{3}{|c|}{ За ступенем відповідності вимогам керівним документам } \\
\hline “Ідеальний” документ & 1 & 1 \\
\hline Поточний документ & 1 & 1 \\
\hline \multicolumn{3}{|c|}{ За ступенем якості висновків } \\
\hline “Ідеальний” документ & 1 & 6 \\
\hline Поточний документ & $1 / 6$ & 1 \\
\hline \multicolumn{3}{|c|}{ За своєчасністю подання документу } \\
\hline “Ідеальний” документ & 1 & 1 \\
\hline Поточний документ & 1 & 1 \\
\hline
\end{tabular}

За результатами парних порівнянь (таблиця 4) визначаються відносні пріоритети поданого $B_{П i}$ та “ідеального" $B_{\mathrm{I} i}$ документів за кожним $i$-м частковим показником якості:

за показником достовірності інформації

$$
\mathrm{B}_{\text {Ід }}=0,67, \mathrm{~B}_{\text {Пд }}=0,33 ;
$$

за показником актуальності інформації

$$
\mathrm{B}_{\text {IA }}=0,75, \mathrm{~B}_{\Pi \mathrm{A}}=0,25 \text {; }
$$

за показником повноти інформації

$$
\mathrm{B}_{\text {IП }}=0,8, \mathrm{~B}_{\Pi \Pi}=0,2 ;
$$

за показником відповідності вимогам керівним документам

$$
\mathrm{B}_{\mathrm{IK}}=0,5, \mathrm{~B}_{\Pi К}=0,5 ;
$$

за показником якості висновків

$$
\mathrm{B}_{\mathrm{IB}}=0,86, \mathrm{~B}_{\Pi \mathrm{B}}=0,14 ;
$$

за своєчасністю подання документу

$$
\mathrm{B}_{\mathrm{IC}}=0,5, \mathrm{~B}_{\Pi \mathrm{C}}=0,5 .
$$

Далі відповідно до формули розраховуються коефіцієнти відносної ваги “ідеального” та поточного (поданого) документу:

$$
\mathrm{P}_{\mathrm{I}}=0,644 ; \mathrm{P}_{\Pi}=0,298 \text {. }
$$

За формулою (1) розраховується значення інтегрального показника ступеня відповідності поданого (поточного) документу вимогам до інформаційних документів

$$
\mathrm{U}=\frac{\mathrm{P}_{\Pi}}{\mathrm{P}_{\mathrm{I}}}=46 \% .
$$

За значенням інтегрального показника $U$ відповідно до таблиці 3 визначається оцінка якості виконання поданого на розгляд інформаційного документу. В даному випадку $(U=46$ \%) поданий документ оцінюється як документ середньої цінності.

\section{Висновки й перспективи подальших досліджень}

Аналіз наведених результатів дозволяє зробити висновок, що переваги запропонованої методики оцінювання якості виконання інформаційних документів полягають у наступному:

відсутність необхідності пошуку функціональної залежності якості виконання документу від показників;

використання парних порівнянь часткових критеріїв за шкалою відношень дозволяє не проводити нормування метричних критеріїв та зменшує помилку під час перетворення якісних характеристик в числові;

можливість отримання додаткової інформації за рахунок ієрархічного представлення елементів структури завдання та чіткий вираз суджень;

можливість зміни кількості показників, які використовуються для оцінювання якості виконання документів, без зміни структури моделі оцінки;

об’єднання часткових показників якості виконання документів в групи показників та проведення оцінювання за однією групою показників без врахування інших груп;

за умов визначення значень пріоритетів загальних та часткових показників якості виконання інформаційних документів за судженням 10-15 експертів може бути забезпечена 
достовірність оцінки документу не нижче 0,8 [8].

Подальшим напрямком дослідження в цій галузі може бути розробка методики оцінки

\section{Лimepamypa}

1. Калашніков С.М., Гаценко С.С., Шишацький А.В. Аналіз характеру сучасних воєнних конфліктів International scientific and practical conference "Challenges of hybrid war: information dimension": conference proceedings, August 16-17, 2019. Vilnius: Izdevnieciba “Baltija Publishing”. pages 24-27. 2. Закон України „Про розвідувальні органи України” // Відомості Верховної Ради, № 19, 2001. - С. 94. 3. Іващенко Г.І. Обгрунтування рекомендіцій щодо удосконалення статутних документів Збройних Сил України для підготовки і ведення збройної боротьби в сучасних умовах: Дисертація канд. військ. наук: 20.01.05. - К., 2004. - 226 с. 4. Василенко І.С., Макар А.Б. Уточнення змісту показників оцінювання виконання інформаційних (інформаційно-аналітичних) документів // Вісник воєнної розвідки, 2006. - № 12. - С. 66 - 70. 5. Саати Т. Принятие решений. Метод анализа иерархий / Пер. с англ. Р. Г. Вачнадзе. - М.: Радио и связь, 1993. - С. 23 69. 6. Литвак Б. Г. Экспертные оценки и принятие решений / Б.Г. Литвак. - М.: Патент, 1996. - 271 с.ISBN 5-7518-0010-9. 7. Development of methodology for complex processing of geopatronic data in the geoinformation system of special purpose in conditions of diversity and nenophynedy A. Koshlan, O. Salnikova, M. інформаційно-аналітичної діяльності в цілому, одним із вхідних даних для якої будуть результати оцінювання інформаційних документів.

\section{МЕТОДИКА ОЦЕНИВАНИЯ ИНФОРМАЦИОННЫХ ДОКУМЕНТОВ В ИНТЕРЕСАХ ОБЕСПЕЧЕНИЕ ИНФОРМАЦИОННОЙ ДЕЯТЕЛЬНОСТИ}

Chekhovska, R. Zhyvotovskyi, Ye. Prokopenko, T. Hurskyi, A. Yefymenko, Ye. Kalashnikov, S. Petruk, A. Shyshatskyi Eastern-european journal of enterprise technologies. Vol. 5, No 9 (95) pp. 35-45, 2019: Information and controlling system. 8. Яхина Е.П. Методы оценки информационных систем / Е. П. Яхина // В мире научных открытий. 2010. - № 3 (09). - Часть 1. - С. 63-66. 9. Method of Immunity Minimization of the Free Platform ed Inertial Navigation System of Unmanned Aircrafts R. Bieliakov, S. Hatsenko, O. Fesenko, R. Zhyvotovskyi, S. Petruk, 2nd Ukraine Conference on Electrical and Computer Engineering Lviv, Ukraine, July 2-6, pp. 803-808, 2019. 10. S. Kalantaievska, H. Pievtsov, O. Kuvshynov, A. Shyshatskyi, S. Yarosh, S. Gatsenko, H. Zubrytskyi, R. Zhyvotovskyi, S. Petruk and V. Zuiko. Method of integral estimation of channel state in the multiantenna radio communication systems. // Eastern-European Journal of Enterprise Technologies. Vol 5, No 9 (95) (2018): pp 60-76. DOI: https://doi.org/10.15587/1729-4061.2018.144085. 11. Ткаченко Н.О. Розробка критеріїв для оцінки інформаційних наукових ресурсів в Інтернет / Н.О. Ткаченко// Наукові праці Донецького національного технічного університету. Серія: Обчислювальна техніка та автоматизація. - 2013. - Вип. 2 (25). - С. 136-143

\section{Виталий Владимирович Зуйко (кандидат военных наук, доцент) Сергей Анатолиевич Мельник \\ Иван Николаевич Лукянчиков Алексей Васильевич Повещенко}

\section{Национальный университет обороны Украины имени Ивана Черняховского, Киев, Украина}

В статье предлагается решение актуальной научной задачи совершенствования научнометодического аппарата оченивания информационных документов при проведении разведывательноинформационной деятельности в системе военной разведки. Разведывательно-информационная деятельность - это непрерывный процесс, который включает комплекс мероприятий по организации и ведения в общей системе военной разведки разведывательно-информационной, информационной и информационно-аналитической работы для предоставления разведывательной информации ее потребителям. Собрать в определенные сроки, оперативно обработать, проанализировать и вовремя доложить это является главным и решающим задачей разведывательно-информационной деятельности в интересах обеспечения принятия решения. Особенностью современной разведывательно-информационной деятельности является решение широкого круга интеллектуальных по содержанию задач, результатами которых является разработка информационных документов. Оиенка качества их выполнения является составной частью оценки информационно-аналитической деятельности в цзелом.

Для решения задач эффективной информаџионно-аналитической деятельности предложена методика оценивания информащионных документов. Методика основана на методе анализа иерархий, который позволяет принимать решения на основе неформализованных показателей, которые невозможно описать аналитическими зависимостями. Предложенная методика позволит повысить качество оченивания информационных документов.

Ключевые слова: разведывательно-информационная деятельность; военная разведка; информационные документы; разведьвательная информация. 


\title{
METHOD OF EVALUATION INFORMATION DOCUMENTS IN INTEREST PROVIDING INFORMATION ACTIVITIES
}

\author{
Vitallii Zuiko (Candidate of Military Sciences, assistant professor) ${ }^{1}$ \\ Serhii Melnyk ${ }^{1}$ \\ Ivan Lukianchikov ${ }^{l}$ \\ Oleksii Poveshchenko
}

\section{National Defence University of Ukraine named after Ivan Cherniakhovsky, Kyiv, Ukraine}

The article proposes the solution of the actual scientific task of improving the scientific and methodological apparatus of evaluating information documents in conducting intelligence and information activities in the military intelligence system. Intelligence is a continuous process that includes a set of measures for organizing and conducting intelligence, information and analytical work in the general military intelligence system to provide intelligence to its customers. Collect in a timely manner, promptly process, analyze and timely report is the main and decisive task of intelligence and information activities in the interests of decision-making. The peculiarity of modern intelligence-information activity is the solution of a wide range of intellectual tasks, the results of which are the development of information documents. Assessment of the quality of their implementation is an integral part of the evaluation of information and analytical activity as a whole.

For the decision of tasks of effective intelligence and information activities the method of evaluation of informative documents is offered. A method is based on the method of analysis of hierarchies, which allows to make a decision on the basis of unformalized indexes which it is impossible to describe analytical dependences. The offered method will allow to promote quality of evaluation of informative documents.

Key words: intelligence; reconnaissance; information documents; intelligence information.

\section{References}

1. Kalashnikov Ye.M., Gaczenko S.S., Shishacz kij A.V. Anali'z kharakteru suchasnikh voyennikh konfli'kti'v International scientific and practical conference "Challenges of hybrid war: information dimension": conference proceedings, August 16-17, 2019. Vilnius: Izdevnieciba "Baltija Publishing”. pages 24-27. 2. Zakon Ukrayini „Pro rozvi duval'ni organi Ukrayini” // Vi'domosti Verkhovnoyi Radi, \# 19, 2001. - S. 94. 3. Ivashhenko G.I . Obgruntuvannya rekomendi czi j shodo udoskonalennya statutnikh dokumenti`v Zbrojnikh Sil Ukrayini dlya pi dgotovki i’ vedennya zbrojnoyi borot'bi $\mathrm{v}$ suchasnikh umovakh: Disertaczi 'ya kand. vi'js`k. nauk: 20.01.05. - K., 2004. - 226 s. 4. Vasilenko I .S., Makar A.B. Utochnennya zmi`stu pokazniki`v oczi`nyuvannya vikonannya i’nformaczi`jnikh (i'nformaczi’jno-anali`tichnikh) dokumenti'v // Vi'snik voyennoyi rozvi'dki, 2006. - \# 12. S. 66 - 70. 5. Saati T. Prinyatie reshenij. Metod analiza ierarkhij / Per. s angl. R. G. Vachnadze. - M.: Radio i svyaz', 1993. - S. 23-69. 6. Litvak B. G. E'kspertny'e oczenki i prinyatie reshenij / B.G. Litvak. - M.: Patent, 1996. - 271 s.- ISBN 5-7518-0010-9. 7. Development of methodology for complex processing of geopatronic data in the geoinformation system of special purpose in conditions of diversity and nenophynedy A. Koshlan, O. Salnikova, M. Chekhovska, R. Zhyvotovskyi, Ye. Prokopenko, T. Hurskyi,
A. Yefymenko, Ye. Kalashnikov, S. Petruk, A. Shyshatskyi Eastern-european journal of enterprise technologies. Vol. 5, No 9 (95) pp. 35-45, 2019: Information and controlling system. 8. Yakhina E.P. Metody oczenki informaczionny'kh sistem / E. P. Yakhina // V mire nauchny'kh otkry`tij. - 2010. - \# 3 (09). - Chast' 1. - S. 6366. 9. Method of Immunity Minimization of the Free Platform ed Inertial Navigation System of Unmanned Aircrafts R. Bieliakov, S. Hatsenko, O. Fesenko, R. Zhyvotovskyi, S. Petruk, 2nd Ukraine Conference on Electrical and Computer Engineering Lviv, Ukraine, July 26, rr. 803-808, 2019. 10. S. Kalantaievska, H. Pievtsov, O. Kuvshynov, A. Shyshatskyi, S. Yarosh, S. Gatsenko, H. Zubrytskyi, R. Zhyvotovskyi, S. Petruk and V. Zuiko. Method of integral estimation of channel state in the multiantenna radio communication systems. // EasternEuropean Journal of Enterprise Technologies. Vol 5, No 9 (95) (2018): rr 60-76. DOI: https://doi.org/10.15587/17294061.2018.144085. 11. Tkachenko N.O. Rozrobka kriteri`yiv dlya oczi`nki i’nformaczi`jnikh naukovikh resursi'v v I'nternet / N.O. Tkachenko// Naukovi` praczi Donecz'kogo naczi'onal'nogo tekhni'chnogo uni'versitetu. Seri 'ya: Obchislyuval'na tekhni ka ta avtomatizaczi`ya. 2013. - Vip. 2 (25). - S. 136-143 